Karolina Lisczyk

(Uniwersytet Śląski, Katowice,

e-mail: karolina.lisczyk@us.edu.pl)

ORCID: 0000-0002-8741-1595

\title{
SZACUN, SZACUNECZEK, USZANOWANKO! O DERYWATACH WYRAŻAJĄCYCH SZACUNEK (?)
}

Przejawem szacunku w relacjach międzyludzkich jest przede wszystkim jego okazywanie (poprzez grzeczność, przestrzeganie obowiązujacych zasad itp.). Poszukując słownych sposobów wyrażania szacunku, z pewnością należałoby wskazać czasownik szanować oraz synonimiczne wobec niego analityzmy werbo-nominalne typu darzyć szacunkiem czy żywić szacunek. Współcześnie, zwłaszcza w rejestrze potocznym, można jednak zaobserwować również inne określenia - należą do nich neologizmy słowotwórcze, m.in. szacun, szacuneczek oraz uszanowanko. Celem niniejszego artykułu jest charakterystyka gramatyczno-semantyczna wskazanych derywatów (marginalnie również innych), pozwalająca odpowiedzieć na pytanie, czy można je uznać za synonimy rzeczowników szacunek oraz uszanowanie. W określeniu tego istotny będzie przegląd definicji leksykograficznych podstaw słowotwórczych (na podstawie słowników współczesnej i dawnej polszczyzny), odniesienie do dotychczasowych ustaleń lingwistów, przede wszystkim jednak - analiza przykładów użycia zaczerpniętych $z$ Internetu za pomoca wyszukiwarki korpusowej Monco PL i internetowej Google, przeprowadzona przy uwzględnieniu założeń słowotwórstwa strukturalnego.

\section{SZACUNEK}

Jak podaje Wiesław Boryś, rzeczownik szacunek został zapożyczony $\mathrm{w}$ okresie staropolskim $\mathrm{z}$ języka niemieckiego (Schatzung 'szacowanie, ocena; poważanie'). W XV w. funkcjonował w postaci zaadaptowanej ortograficznie (szacunk), a w obecnej notowany jest w tekstach od XVI w. [Boryś 2005, 591]. ${ }^{1}$ W okresie od staropolszczyzny do współczesności znaczenie tego wyrazu ulegało zmianom, na co wskazuje przegląd lek-

1 Autorzy Elektronicznego słownika języka polskiego XVII i XVIII w. datuja jednak najwcześniejsze poświadczenie na lata 1656-1688. 
sykograficzny, ${ }^{2}$ jednak konsekwentnie wyróżniany jest sens odnoszący się przede wszystkim do określania wartości czegoś, a dziś również do wielkości lub zasięgu czegoś [por. ISJP, WSJP]. W słownikach dawnej polszczyzny znaczenie to wskazywane było jako prymarne i stanowiło nominalny odpowiednik czasownika szacować (por. np. 'określać cenę czego, oceniać' [ESJPXVII/XVIII]). Leksykony rejestrujace stan polszczyzny do XX w. notuja także inne znaczenia, związane ze wskazanym:

- cennik, taksa [SWil, SWar],

- cena czegoś [SStp, ESJPXVII/XVIII, ND, SL, SWil, SWar, SJPD z kwalifikatorem przestarzały],

- naznaczanie poboru [ND, SL, SWil, SWar],

- podatek szacunkowy [SWar],

- pieniądze [SWar].

Interesujące mnie znaczenie, odnoszące się do poważania kogoś, po raz pierwszy odnotowane zostało w SL ( $z$ kwalifikatorem Moral.), dopiero jednak w SJPD znajduje się w artykule hasłowym na pierwszej pozycji. Można uznać, że nastapiło tu przeniesienie znaczenia na zasadzie metafory - szacunek oznaczał pierwotnie cenę, wartość czegoś, później analogicznie również wartość (moralna) kogos. ${ }^{3} \mathrm{~W}$ odniesieniu do tego znaczenia definicje proponowane przez leksykografów mają (zwłaszcza w słownikach dawnej polszczyzny) najczęściej charakter synonimiczny, ${ }^{4}$ a do podawanych bliskoznaczników szacunku należą: szanowanie, poszanowanie, uszanowanie, poważanie, czczenie, cześć, respekt. Interesujące na tym tle sa dwie definicje - zamieszczone w ISJP ('Szacunek to stosunek, jaki mamy do osób, działań, wartości itp., które szanujemy.') oraz WSJP ('szczególne względy i uznanie okazywane komuś lub czemuś'). Obydwie wskazują bowiem na to, że szacunek to określona postawa, zachowanie, sposób postępowania wobec kogoś. Jest to o tyle istotne, że językoznawcy zwracają uwagę na konieczność odróżniania szacunku-postawy od szacunku-

2 Oglądowi poddane zostały następujace leksykony: Słownik staropolski (dalej: SStp), Elektroniczny słownik języka polskiego XVII i XVIII wieku (ESJPXVII/XVIII), Nowy dykcjonarz, to jest Mownik polsko-niemiecko-francuski M.A. Trotza (ND), Słownik języka polskiego S.B. Lindego (SL), Słownik języka polskiego, tzw. wileński (SWil), Słownik języka polskiego, tzw. warszawski (SWar), Słownik ilustrowany języka polskiego M. Arcta (SIJP), Słownik języka polskiego pod red. W. Doroszewskiego (SJPD), Inny słownik języka polskiego (ISJP), Uniwersalny słownik języka polskiego (USJP) i Wielki słownik języka polskiego PAN (WSJP).

3 Warto dodać, że SL, SWil i SWar notują również takie znaczenie rzeczownika szacunek, które wskazuje na negatywną postawę wobec kogoś (por. definicję ze SWar 'krytyka złośliwa, obmowa, szkalowanie, oszczerstwo').

4 Problemowi temu poświęciła artykuł Zofia Zaron, przeprowadzajac testy semantyczne dla rzeczowników poważanie, poszanowanie, uznanie, podziw, autorytet. Badaczka doszła do wniosku, że tylko znaczenie dwóch pierwszych niemal całkowicie pokrywa się $z$ sensem, jaki niesie wyraz szacunek [zob. Zaron 2006]. 
uczucia, które może, lecz nie musi być wyrażane [por. Zaron 2006, 495; Kleszczowa 2018, 164]. Przyjęcie wyłącznie jednej możliwości interpretacji semantycznej skutkuje w badaniach lingwistycznych określonym profilem opisu - dość porównać odnosząca się do uczucia eksplikację Anny Wierzbickiej, według której formuła $X$ szanuje $Y$ oznacza ' $\mathrm{X}$ w kontakcie z Y czuje to, co zwykle czujemy w kontakcie z kimś, o kim sadzimy, że jest taki, jaki on powinien być' [Wierzbicka 1971,72 ], ${ }^{5}$ oraz podział, w którym Iwona Nowakowska-Kempna wyróżniła grupę szacunku w obrębie postaw emocjonalnych [Nowakowska-Kempna 1986, tabela 2]. Wydaje się, że kontekst użycia omawianego rzeczownika pozwala niejednokrotnie rozstrzygać, czy mowa o uczuciu czy jego okazywaniu, $z$ drugiej jednak strony określone postępowanie wobec kogoś może być przecież odzwierciedleniem jego odczuć (wówczas nie da się oddzielić tych dwóch aspektów). Na zależność postępowania od stanu emocjonalno-mentalnego zwróciła uwagę Zofia Zaron, piszac: „postawa oprócz dyspozycji psychicznej musi zawierać w sobie działanie, dążność do realizacji tej dyspozycji” [Zaron 1985, 8]. Choć więc zarysowanego podziału nie można traktować bezwzględnie, wydaje się, że rozróżnienie to może być istotne dla opisu wymienionych w tytule określeń szacun, szacuneczek i uszanowanko, sygnalizujących przede wszystkim czyjeś nastawienie (uczucie) wobec drugiej osoby, jej cech lub działań.

\section{SZACUN}

Wyraz szacun to neologizm słowotwórczy ${ }^{6}$ motywowany wyrazem szacunek, utworzony poprzez odcięcie niefleksyjnej cząstki -ek. Ze względu na mechanizm derywacyjny można zaliczyć go do podgrupy derywatów ujemnych, które Hanna Jadacka określiła jako neologizmy skrótowe, właściwe odmianom środowiskowym polszczyzny - przykładami moga tu być wyrazy anabol, dement, merc [Jadacka 2001, 89]. Biorąc pod uwage funkcję formantu, neologizmy podane przez $\mathrm{H}$. Jadacka jako przykłady są derywatami tautologicznymi, a ściślej - w myśl podziału, który zaproponował Tomasz Kurdyła - derywatami tautologicznymi stylowymi (odmianowymi). Formant pełni tu bowiem dwie funkcje - strukturalna i stylowa, w konsekwencji czego wyrazy fundujący i fundowany w niektórych kontekstach nie są wzajemnie zamienialne [Kurdyła 2002,

5 Badaczka analizowała czasownik szanować, sądze jednak, że rozważania te można również odnieść do rzeczownika szacunek.

6 Terminu tego używam zgodnie $z$ definicja Hanny Jadackiej, według której neologizmy słowotwórcze to „podklasa neologizmów leksykalnych, wyodrębniona ze względu na kryterium formalne". Biorac pod uwagę podział na neologizmy nominatywne i ekspresywne, omawiany derywat należy do tej drugiej klasy [Jadacka 2001, 37]. 
184]. Według Alicji Nagórko odcinanie cząstki -ek od podstaw słowotwórczych motywowane jest chęcia pozbawienia ich podobieństwa do zdrobnień: „formy „ujemne” sa natomiast szorstkie i lepiej odpowiadaja temu chłodnemu modelowi uczuć, jaki panuje w subkulturach młodzieżowych (bycie „cool”)” [Nagórko 2012, 196]. Renata Grzegorczykowa z kolei, piszacc o derywatach wstecznych, zaznaczyła, że są one

sygnałem pewnego stylu familiarno-wulgarnego, użycie ich informuje o sposobie bycia mówiącego, ale niekoniecznie o jego emocjonalnym ustosunkowaniu do desygnatu [Grzegorczykowa 1979, 56].

Przegląd wypowiedzeń $z$ wyrazem szacun prowadzi jednak do wniosku, że choć derywat ten został formalnie utworzony w ten sam sposób, co neologizmy typu anabol, dement, merc, to jednak nie można sprowadzić różnicy między wyrazami szacunek i szacun wyłącznie do nacechowania stylistycznego.

Opis użycia tego drugiego rzeczownika warto rozpocząc od spostrzeżeń dotyczących jego właściwości fleksyjno-składniowych. Wyraz szacun używany jest bowiem niemal wyłącznie w formie kanonicznej, ${ }^{7}$ a zatem zasadniczo jest nieodmienny formalnie. Biorąc pod uwagę właściwości syntaktyczne, można wskazać kilka charakterystycznych sposobów jego użycia, dzieląc je na dwie grupy.

Pierwsza obejmuje przykłady, w których wyraz szacun stanowi albo samodzielne wypowiedzenie, kończone wykrzyknikiem lub kropka, albo jego ostatni w porządku linearnym składnik. W obu wypadkach nie jest on związany syntaktycznie $z$ poprzedzającym go wypowiedzeniem lub jego częścią, jednak pozostaje w ścisłym związku kontekstowym $z$ wcześniejszym zdaniem, stanowiąc $\mathrm{w}$ istocie odrębny komentarz lub słowną reakcję mówiącego na określoną sytuację, ${ }^{8} \mathrm{np}$. :

(1) (...) nigdy nie zadziałał $w$ sposób, który budziłby mój niesmak - wszystko elegancko, pro i z zachowaniem zasad fair play. Szacun!

7 Materiał wyekscerpowany za pomoca wyszukiwarki korpusowej Monco PL obejmuje 4775 przykładów użycia formy szacun i jedynie 28 przykładów zdań, w których wyraz ten został odmieniony przez przypadki (szacunu-12, szacunem - 14, szacunie - 2). Niewykluczone przy tym, że niektóre spośród tych przykładów (zwłaszcza gdy idzie o formę szacunu) to błąd z w zapisie (literówka).

8 Niesyntagmatyczność i kontekstowość opisywanego wyrazu każą zastanowić się nad jego statusem jako części mowy. Wskazane cechy pozwalają bowiem interpretować takie użycie (np. zdanie (2)) jako dopowiedzenie [por. Laskowski $1998,58]$. Być może należałoby więc traktować użyty w tekstach wyraz szacun jako realizację dwóch jednostek leksykalnych, różniących się właściwościami syntaktycznymi. Kwestia ta wymaga jednak odrębnych analiz, dlatego nie poświęcam jej tu więcej miejsca.

9 Źródła przykładów wraz $z$ data ich opublikowania w Internecie podaję w netografii (metadane dla przykładów 1-17 pozyskane dzięki wyszukiwarce 
(2) „Wspaniałe wyznanie! Nie każdego mężczyznę byłoby stać na takie słowa, szacun”- napisała jedna $z$ internautek.

W przykładach tych można dostrzec dążenie do ekonomizacji języka - wyraz szacun używany jest zamiast dłuższych konstrukcji (np. szanuje go za to, jego zachowanie budzi mój szacunek itp.). ${ }^{10}$ Warto jednak zauważyć, że w takich samych kontekstach występuje również nienacechowany rzeczownik szacunek - por.:

(3) Facet potrafi myśleć - szacunek!

(4) Tymczasem na materiale poniżej... trzylatek sam i to bardzo sprawnie porusza sie minibikiem. Szacunek!

Wydaje się, że za pomoca wskazanych konstrukcji użytkownicy polszczyzny nie wyrażaja czci lub poważania; jest to raczej przejaw pochwały, sympatii, a jego odpowiednikiem mógłby być wyraz brawo - dość przywołać jego definicję: 'wykrzyknik wyrażajaccy aprobatę i ciepłe uczucia; doskonale, świetnie, wspaniale, pięknie' [USJP]. Należy przy tym dodać, że wyraz szacun stawiany jest często w szeregu $z$ wykrzyknikiem brawo, ${ }^{11}$ por. np.:

(5) Myślę, że oprócz decyzji o przekazaniu nagrody, należy powiedzieć o świetnym wysteppie pana Kacpra. Brawo i szacun.

i określany przymiotnikami ogromny i wielki (które wykazują dużą frekwencję w zakresie łączliwości z rzeczownikiem brawo, najczęściej używanym w liczbie mnogiej).

Druga grupa wypowiedzeń to takie, w których rzeczownik ${ }^{12}$ szacun wchodzi w relacje syntagmatyczne $z$ innymi wyrazami. Często wskazywany jest tu adresat wyrażanych emocji - zarówno w konstrukcjach z przyimkiem dla (szacun + dla $+\mathrm{N}_{\mathrm{Gen}}$ ), ${ }^{13}$ jak i z rzeczownikami osobowymi w wołaczu (szacun $+\mathrm{N}_{\mathrm{voc}}$ ), np.:

Monco PL). Wszystkie przykłady zostały przeze mnie wyekscerpowane w okresie od września do grudnia 2019 r. Sacdzę jednak, że w tym wypadku istotniejsza jest data ich publikacji w Internecie, ilustrująca czas, na który przypada żywotność omawianych derywatów.

10 Jeszcze wyraźniej tendencja ta uwidacznia się w konstrukcjach szacun, że + zdanie podrzędne wyrażające powód, dla którego komuś należy się szacunek (np. szacun, że się przyznałeś - na wzór szanuję to, że się przyznałeś).

11 Częsty jest również szereg szacun i gratulacje, co również można interpretować jako połączenie będące wyrazem czyjegoś uznania.

$12 \mathrm{~W}$ odniesieniu do tych przykładów użycia nie ma watpliwości co do statusu wyrazu szacun jako części mowy.

13 Uzupełnieniem nominalnym wyrażenia szacun dla może być też rzeczownik nieżywotny, np. szacun dla imprezy, dla inicjatywy itp., jednak konstrukcje te sa pewnym skrótem myślowym - za ich pomoca wyrażany jest bowiem sza- 
(6) Wielki szacun dla kibiców, dziękuję za to, że o mnie pamiętali (...).

(7) (...) oddziałowa noworodków i pani doktor sa bardzo miłe i naprawdę dla nich wielki szacun - podsumowała pani Edyta.

(8) Szacun Panowie za Wasza prace (...).

Również w takich połączeniach szacun przede wszystkim jest wyrazem aprobaty czyichś działań, sympatii, a nawet wdzięczności dla kogoś. Znaczenie to jest jeszcze bardziej widoczne w połączeniu mieć u kogoś szacun, zbudowanym na wzór mieć u kogoś plus, ${ }^{14}$ por.:

(9) (...) moim zdaniem $w$ swoim osadzie kierujesz sie przede wszystkim obiektywizmem $i$ zdrowym rozsadkiem, a nie sympatiami $i$ antypatiami politycznymi i masz u mnie za to duży szacun.

(10) (...) jako przedstawicielka Zwiazków Zawodowych Solidarność brałaś udział $w$ protestach, które miały miejsce $w$ Warszawie $i$ za to masz u mnie duży szacun.

Przeglądając zdania $z$ wyrażeniem przyimkowym (szacun + za $+\mathrm{N}_{\text {Acc }}$ ), można $z$ kolei odkryć powody, dla których ktoś darzy inną osobę określanym w ten sposób uczuciem. Obok połączeń typowych również dla rzeczownika szacunek, wskazujących na podziw dla czyichś zalet lub działań (szacun należy się komuś wyłącznie za coś, co oceniane jest pozytywnie, np. szacun za odwage, za wytrwałość, za prace), pojawiaja się również takie, które wyraźnie sygnalizują inne znaczenie, np.:

(11) Zaskoczyt mnie deserem - wielki szacun za to - mówi Nowak.

(12) (...) szacun za udostępnianie tych informacji, bo może do niektórych dotrze, że te matki walczyly o dobro swoich dzieci (...).

Podobnie jak we wcześniejszych przykładach, mowa raczej o pochwale albo wdzięczności dla kogoś. Warto przy tym zauważyć, że znaczenie wskazujące na lubienie lub akceptację (a nie szczególne względy czy cześć) właściwe jest współcześnie także potocznym zdaniom $z$ czasownikiem szanować, konkretnie zaś konstrukcji $i$ ja to szanuję (lub $i$ taki $X$ to ja szanuje), przyłączajacej dopełnienie nieosobowe, np.:

(13) (...) przyzwoicie karmia ludzi, nie napinaja się sztucznie na coś, czym nie sa, maja super miła obsługe. I ja to szanuję.

(14) Duszne poranki, prysznic 4 minuty, nieuprasowane $t$-shirty, Lambrusco $w$ plastikowych kubkach, słodkie pomidory $w$ jednogarnkowych daniach, długie nocne Włochów biesiady. Taki survival to ja szanuję.

cunek (?) dla osób, które przyczyniły się np. do zorganizowania jakiegoś przedsięwzięcia.

14 Fraza ktoś ma plus u kogoś definiowana jest w WSJP następujaco: 'ktoś zyskał sobie czymś czyjąś aprobatę i przychylność lub większą przychylność niż do tej pory'. 
Biorąc pod uwagę lewostronny kontekst wypowiedzeń z rzeczownikiem szacun, należy zauważyć, że nie jest on jedynie potocznym odpowiednikiem wyrazu szacunek - nie wykazuje bowiem łączliwości z czasownikami takimi jak np.: czuć, stracić, odzyskać (w pozyskanej próbie 4775 przykładów brak takich konstrukcji), w innych połączeniach występuje incydentalnie, np. budzić / wzbudzać szacun (po 2 przykłady), oddać komuś szacun (5), zasługiwać na szacun (7) czy mieć szacun do kogoś (22). Trudno zatem zgodzić się z potocznymi definicjami tego wyrazu, stanowiącymi odpowiedź na formułowane przez internautów pytanie o jego znaczenie - por. np.:

Szacun to odpowiednik starego słowa szacunek a oznacza ono w sensie poważanie, uszanowanie, poszanowanie, respekt, atencja, estyma, pokłon. ${ }^{15}$

Wyraz szacun należałoby bowiem definiować jako uznanie dla jakiejś osoby wyrażane ze względu na jej zalety lub określone działania. Bliskoznacznikiem nie jest więc rzeczownik szacunek, a raczej uznanie lub docenianie.

$\mathrm{Na}$ koniec tej części rozważań warto dodać, że choć analizowany wyraz szacun właściwy jest rejestrowi potocznemu, przenika on także do polszczyzny ogólnej, choć raczej na prawach stylizacji na luz i język młodzieżowy. Za przykład moga posłużyć: tytuł filmu Szacun, bracie! (w oryginale: Ti stimo fratello, co po włosku oznacza dosłownie: 'szanuję cię bracie'), tytuł książki o bramkarzu piłki ręcznej Szacun. Andrzej Marszałek, nazwa cyklicznie organizowanego konkursu karaoke Szansa na Szacun (nawiąująca do tytułu programu Szansa na sukces), nazwa nagrodzonej kampanii społecznej z 2014 r. Szacun Tropików czy nazwy gier planszowych - edukacyjnej Czy wiesz, co wiem? Szacun! $!^{16}$ oraz nawiazującej do kreskówki dla dorosłych Blok Ekipa - szacun na rejonie. Wykorzystanie potocyzmu szacun pełni tu więc głównie funkcję marketingowa i jest przykładem konieczności uwzględniania zwyczajów językowych klientów lub odbiorców określonych komunikatów [o zjawisku tym pisała np. Anna Dabrowska 2016, 78]. Niewatpliwie sprzyja przy tym ekspansji analizowanego wyrazu w języku.

15 https://zapytaj.onet.pl/Category/001,003/2,5999741,co_to_znaczy_szacun_.html [dostęp online: 3.11.2019].

${ }^{16}$ Użyte tu słowo szacun nawiąuje nie tylko do rzeczownika szacunek, ale i czasownika szacować - uczestnicy gry oceniaja bowiem (szacuja) wyniki swój i konkurentów. 


\section{SZACUNECZEK}

Wyraz szacuneczek został utworzony zgodnie $z$ regułami derywacji sufiksalnej właściwymi tworzeniu form deminutywnych. Krystyna Waszakowa, piszacc o przyrostkach -i(y)k, -ek, -ka, -ko w kontekście problemu wartościowania w słowotwórstwie, zauważyła:

sufiksy te oprócz funkcji czysto deminutywnej, ujawniającej się w formacjach typu tacka, notesik, zwykle wnosza do derywatu nacechowanie pozytywne (aprobatę) i zwiazane $z$ tym „ciepłe” emocje, por. kotek 'mały (miły) kot'. Otóż formanty te moga wystapić także w roli nosiciela negatywnej oceny nadawcy wobec przedmiotu (stanu rzeczy) nazwanego podstawą słowotwórczą. Idzie tu o ich funkcję lekceważąco-ironiczna, ujawniajaca się np. w derywatach typu poezyjka wobec poezja (...) [Waszakowa 1991, 183].

Derywat szacuneczek nacechowany jest przede wszystkim pozytywnie (w przeglądanej próbie wypowiedzenia ironiczne występują incydentalnie), a znaczenie i konteksty jego użycia nie różnią się od tych, które zostały omówione dla wyrazu szacun. W tekstach internetowych szacuneczek odnotowywany jest jednak znacznie rzadziej. ${ }^{17}$ Oto kilka przykładów:

(15) $Z$ taka ferajna jak na Grzybowskiej trzymać naprawdę warto. Szacuneczek!

(16) Na pewno nie narzekał na brak opcji, gdy $w$ Wiśle nie było kolorowo, a mimo to pozostał $w$ klubie, za co również szacuneczek.

(17) Wciagająca fabuła, urok i klimat Paryża, piękne krajobrazy stolicy Francji, innymi słowy - niecodzienna komedia romantyczna, dlatego też wielkie ukłony $i$ szacuneczek dla pana Allena.

W przykładach tych wyraz szacuneczek można bez zmiany znaczenia i rejestru stylistycznego zastapić określeniem szacun, co dowodzi synonimii obu tych wyrazów derywowanych od rzeczownika szacunek. Być może nieekonomiczna językowo forma deminutywna jest w tym wypadku wyrazem mody na zdrabnianie [por. Mańczak 1980, 2011; Miodek 2012], a może próbą zróżnicowania obu derywatów, „ocieplenia” szorstko brzmiącego wyrazu szacun, przy zachowaniu luzu językowego właściwego nieoficjalnym sytuacjom komunikacyjnym.

17 Za pomoca wyszukiwarki korpusowej Monco PL pozyskałam 206 przykładów użycia wyrazu szacuneczek (forma szacun odnotowana została 4775 razy); dane $z$ 8.11.2019. 


\section{USZANOWANKO}

Forma deminutywna jest także derywat uszanowanko ${ }^{18}$ - zdrobnienie od rzeczownika uszanowanie, utworzonego od czasownika uszanować, którego pierwsze poświadczenie w polszczyźnie datowane jest na połowę XVIII wieku [ESJPXVII/XVIII]. Znaczenia tego czasownika, odnotowane również w leksykonach dawnej polszczyzny, zbiera SJPD: 1. 'okazać należny szacunek, wzgląd, nie uchybić komu'; 2. 'nie naruszyć czego, zachować co'; 3. daw. 'oddać cześć, uczcić'. Analogicznie rzeczownik uszanowanie oznacza 'poważanie, poszanowanie, szacunek, cześć'. Forma grzecznościowa (moje) uszanowanie, stosowana przy powitaniu lub pożegnaniu, jest dookreślana pragmatycznie w niektórych współczesnych leksykonach jako wyrażenie przestarzałe kierowane do osoby, której należy się specjalny szacunek [USJP], stosowane współcześnie przez starszych mężczyzn [ISJP]. ${ }^{19}$

Derywat uszanowanko używany jest w dwóch znaczeniach, nawiązujących zarówno do rzeczownika uszanowanie, jak i formuły grzecznościowej, której jest on komponentem. Użycie rzeczownikowe jest rzadsze, jednak - podobnie jak w wypadku form szacun czy szacuneczek - wyraz uszanowanko używany jest $\mathrm{w}$ konstrukcjach $\mathrm{z}$ wyrażeniami przyimkowymi za coś lub dla kogoś, np.:

(18) Jeśli jest to (...) chwyt marketingowy, który ma przyciagnać uwage do firmy, to należy się uszanowanko za świetny pomyst.

(19) Uszanowanko dla tej pani za ostatnie zdanie.

Także i tu oznacza on przede wszystkim gratulacje, aprobatę czy docenienie czyjegoś zachowania. $\mathrm{W}$ tym znaczeniu rzeczownik uszanowanko jest odmienny i tak jak uszanowanie może występować w formie narzędnika - dość porównać zdania, kolejno $z$ wyrazem uszanowanko i uszanowanie, w których mimo podobnego kontekstu widoczna jest różnica stylistyczna - pierwsze zdanie jest bowiem wyraźnie żartobliwe:

(20) Gdzieś z boku dostrzegam dwóch panów, którzy kiwaja głowami z uszanowankiem.

(21) Przywitał się bezpardonowo (...) i skinał głowa z uszanowaniem.

18 Za pomoca wyszukiwarki Monco PL wyekscerpowałam jedynie 50 przykładów użycia (stąd cytaty 18-23 stanowią wynik bezpośredniego wyszukiwania w Internecie), jednak ponad milion poświadczeń można odnaleźć, wpisując zapytanie o ten derywat w wyszukiwarce Google, a zatem nieco mniej niż form szacun (według Google: 1300 000) i znacznie więcej niż szacuneczek (125 000).

19 Małgorzata Marcjanik w Poradni Językowej PWN również zaznaczyła, że jest to zwrot stosowany przez mężczyzn starszego pokolenia. Dodała przy tym: „W ustach młodych ludzi, zwracających się do swoich rówieśników, ma wydźwięk żartobliwy (...)" [https://sjp.pwn.pl/poradnia/haslo/Moje-uszanowanie; 14948. html; dostęp online 11.11.2019]. 
Drugie użycie derywatu uszanowanko to formuła grzecznościowa, stosowana przy powitaniu lub - zdecydowanie rzadziej - przy pożegnaniu. Można uznać ją za żartobliwy wariant wyrażenia moje uszanowanie, którego zdrobniała postać pozbawiona jest powagi, patosu czy szczególnej staranności stylistycznej. Wyraz uszanowanko w takich kontekstach to wykrzyknik, szczególnie często pojawiający się w Internecie na forach lub w grupach dyskusyjnych, np.:

(22) Uszanowanko wszystkim. Za miesiac wybieram się do Edynburga i mam pytanko: jak to jest $z$ polskim samochodem $w$ Szkocji.

(23) Częściej się tu bywało jak nie było auta. A to mniej niż 2 godzinki drogi. Paradoks. Powodzenia i uszanowanko!

W serwisie Wizaz.pl założony został w 2013 r. osobny wątek zatytulowany „Powiedz wszystkim uszanowanko”, ${ }^{20}$ gdzie internauci do dziś (dane $z$ 13.11.2019) w treści swoich postów zamieszczaja najczęściej jedynie lakoniczne powitanie uszanowanko. Czasami rozwijaja swoją wypowiedź, jednak wówczas nieco zmienia się znaczenie analizowanego tu wyrazu - zamiast powitania kogoś oznacza on bowiem radość, zadowolenie $z$ pojawienia się czegoś (stąd rzeczownik łączący się z przyimkiem dla jest nieżywotny), np. uszanowanko dla skończonych wcześniej zajęć; uszanowanko dla kolejnego wygranego konkursu; uszanowanko dla przygotowanego właśnie obiadu. Z jednej strony można uznać, że jest to pochodna formuły powitalnej uszanowanko, przy czym „witane” jest to, co nowe, a jednocześnie wywołujące pozytywne uczucia. $Z$ drugiej jednak pod względem syntaktycznym widać tu analogię do konstrukcji uszanowanko dla kogoś, oznaczającej aprobatę. Podobnie smutek lub niezadowolenie wyrażane sa za pomoca konstrukcji z derywatem zaprzeczonym nieuszanowanko, ${ }^{21} \mathrm{np}$. nieuszanowanko dla bolacego halluksa; nieuszanowanko dla pogody; nieuszanowanko dla wizyty u stomatologa. Wypowiedzenia tego typu, właściwe zapewne raczej osobom młodym, wpisuja się w ekonomiczny językowo (choć wątpliwy stylistycznie) sposób przeczenia, widoczny również w młodzieżowych formach typu przymiotnikowego lub przysłówkowego, jak np. nie halo czy nie wow.

Niewątpliwie źródłem popularności derywatu uszanowanko jest jego obecność w generowanych przez internautów memach $z$ psem rasy shiba (określanym przez użytkowników sieci jako pieseł). Analizowany wyraz występuje w nich we wszystkich wskazanych tu użyciach, a zatem zarówno jako wyraz aprobaty dla kogoś, zadowolenia $z$ czegoś, jak i forma powitania czy pozdrowienia kogoś.

20 https://wizaz.pl/forum/showthread.php?t=724884 [dostęp online: 13.11.2019].

$21 \mathrm{~W}$ Internecie można wyszukać porównywalną liczbę przykładów zapisu łącznego (nieuszanowanko) i rozdzielnego (nie uszanowanko). 


\section{POSZAN, POSZANOWANKO}

Omawiajac grupę derywatów zbudowanych na tym samym rdzeniu, co rzeczownik szacunek lub czasownik szanować, warto także wspomnieć o wyrazach poszan i poszanowanko, podobnych pod względem budowy słowotwórczej do form szacun i uszanowanko, jednak znacznie rzadziej używanych, co skłania do interpretowania ich raczej jako okazjonalizmów. Motywujący je rzeczownik poszanowanie notowany jest w formie odrębnego artykułu hasłowego dopiero w leksykonach XX-wiecznych i definiowany jako synonim rzeczownika szacunek - por. np. definicję z SWar: 'uszanowanie, cześć, szacunek, poważanie, atencja'. Spośród słowników współczesnej polszczyzny jedynie WSJP nie definiuje rzeczownika poszanowanie poprzez odwołanie do synonimów i wyjaśnia jego znaczenie w sposób podkreślający odczasownikowe pochodzenie: książk. 'okazanie, że uznaje się kogoś lub coś za ważne i wartościowe'. ${ }^{22}$

Derywat ujemny poszan najczęściej jest składnikiem potocznego wyrażenia poszan na dzielni, np. ${ }^{23}$ :

(24) (...) na jednym forum dostałem namiar do kołodzieja z Cieszyna-gość ma tam spory poszan na dzielni,

i oznacza uznanie, jakim cieszy się ktoś ze względu na swoje cechy lub działania. Wyraz poszanowanko z kolei, podobnie jak uszanowanko (i rzadka forma szanowanko), używany jest zarówno jako formuła powitalna (por. przykład 25), jak i forma wyrażania szacunku (przykład 26):

(25) Cześć, hej, witajcie, siemanko, poszanowanko!

(26) Nie no... pelne poszanowanko za tak łatwe, a zarazem genialne rozwiazanie.

Wskazane derywaty nie wyczerpują twórczości słowotwórczej użytkowników potocznej polszczyzny - dość wspomnieć formy szacuncio, uszanowaneczko czy szanowaneczko. Ich użycie jest jednak incydentalne i można je uznać za przejaw indywidualnych lub uwarunkowanych sytuacja komunikacyjną efemeryd językowych.

22 Należy jednak dodać, że WSJP nie notuje czasownika poszanować (zakwalifikowanego jako przestarzały już w SJPD), a jego synonim - uszanowaćdefiniuje następująco: 'okazać komuś to, że się go uznaje za wartościowego lub ważnego'.

23 Przykłady 24-26 pozyskałam za pomoca wyszukiwarki Google. Wyszukiwarka korpusowa Monco PL znajduje jedynie 4 przykłady formy poszan i żadnych poświadczeń derywatu poszanowanko. 


\section{WNIOSKI}

Przegląd przykładów użycia neologizmów słowotwórczych odnoszących się do szacunku i szanowania pozwala twierdzić, że przeanalizowane tu wyrazy jedynie w części kontekstów stanowią synonimy stylistyczne rzeczownika szacunek. W komunikacji potocznej, wraz ze wzrostem popularności badanych form, nastapiło częściowe odejście od prymarnego znaczenia - derywaty szacun, szacuneczek, uszanowanko czy poszan, poszanowanko używane sa bowiem w celu wyrażenia aprobaty, uznania, niekoniecznie zaś szczególnych względów czy czci. Niezależnie od tego znaczenia formy uszanowanko i poszanowanko moga dodatkowo nawiazywać do dawnych formuł grzecznościowych i inicjować lub wieńczyć wypowiedź.

Na koniec nie sposób nie wspomnieć o podobieństwie pomiędzy znaczeniem i użyciem analizowanych derywatów a zapożyczonego $z$ angielszczyzny znacznie wcześniej rzeczownika respect (czy młodszych props / / propsy - wynik uniwerbizacji angielskiego proper respekt) [por. Dyszak 2019, 23]. Być może więc obecność analizowanych tu derywatów w polszczyźnie potocznej stanowi kolejna (nowsza) realizację zachowania komunikacyjnego przeszczepionego ze zwyczajów mownych właściwych użytkownikom angielszczyzny.

\section{Bibliografia}

A. Dąbrowska, 2016, Slang na salonach. O ekspansji języka młodzieży na przykładzie komunikatów reklamowych, „Kwartalnik Pedagogiczny” nr 2 (240), s. 77-98.

A. Dyszak, 2019, $Z$ badań nad zjawiskami słowotwórczymi $i$ adaptacyjnymi w „najmłodszej polszczyźnie”, „Język Polski” z. 3, s. 18-31.

R. Grzegorczykowa, 1979, Zarys słowotwórstwa polskiego. Stowotwórstwo opisowe, Warszawa.

H. Jadacka, 2001, System słowotwórczy polszczyzny (1945-2000), Warszawa.

K. Kleszczowa, 2018, Okazywać komuś szacunek - studium semantyczno-składniowe [w:] J. Chojak, Z. Zaron (red.), Ku rzeczom niebłahym, Warszawa, s. $161-170$.

T. Kurdyła, 2002, Luksus słowotwórczy, czyli o tzw. derywatach tautologicznych i funkcjach tworzacych je formantów, „Język Polski” LXXXII, z. 3, s. 178-187.

R. Laskowski, 1998, Zagadnienia ogólne morfologii [w:] R. Grzegorczykowa, R. Laskowski, H. Wróbel (red.), Gramatyka współczesnego języka polskiego. Morfologia, t. 1, Warszawa, s. 27-86.

W. Mańczak, 1980, Moda na zdrobnienia, „Język Polski” z. 1, s. 69-71.

W. Mańczak, 2011, Jeszcze o modzie na zdrobnienia, „Język Polski” z. 2-3, s. $218-219$.

J. Miodek, 2012, Szaleństwo zdrobnień trwa!, „Język Polski” z. 5, s. 402.

A. Nagórko, 2012, Podręczna gramatyka języka polskiego, Warszawa. 
I. Nowakowska-Kempna, 1986, Konstrukcje zdaniowe z leksykalnymi wykładnikami predykatów uczuć, Katowice.

K. Waszakowa, 1991, O wartościowaniu w słowotwórstwie, „Poradnik Językowy” z. 5-6, s. 180-187.

A. Wierzbicka, 1971, Kocha, lubi, szanuje. Medytacje semantyczne, Warszawa.

Z. Zaron, 1985, Wybrane pojęcia etyczne $w$ analizie semantycznej (Kochaj bliźniego swego), Wrocław.

Z. Zaron, 2006, Problemy z definicja synonimiczna (na przykładzie definiowania szacunku 1), „Prace Filologiczne” t. LI, s. 493-503.

\section{Slowniki}

W. Boryś, 2005, Słownik etymologiczny języka polskiego, Kraków.

ESJPXVII/XVIII - Elektroniczny słownik języka polskiego XVII i XVIII wieku [dostęp online: https://sxvii.pl/].

ISJP - M. Bańko (red.), 2000, Inny słownik języka polskiego, Warszawa.

ND - M.A. Trotz, 1764, Nowy dykcjonarz, to jest Mownik polsko-niemiecko-francuski, Lipsk.

SIJP - M. Arct, 1916, Słownik ilustrowany języka polskiego, Warszawa.

SJPD - W. Doroszewski (red.), 1958-1969, Słownik języka polskiego, Warszawa.

SL - S.B. Linde, 1807-1814, Słownik języka polskiego, Warszawa.

SStp - S. Urbańczyk (red.), 1953-2002, Słownik staropolski, Kraków.

SWar - J. Karłowicz, A.A. Kryński, W. Niedźwiedzki (red.), 1900-1927, Słownik języka polskiego, tzw. Słownik warszawski, Warszawa.

SWil - A. Zdanowicz i in., 1861, Słownik języka polskiego, tzw. Słownik wileński, Warszawa.

USJP - S. Dubisz (red. nauk.), 2003, Uniwersalny słownik języka polskiego, Warszawa.

WSJP - P. Żmigrodzki (red.), Wielki słownik języka polskiego PAN, [dostęp online: https://www.wsjp.pl/].

\section{Netografia}

https:/ / zapytaj.onet.pl/Category/001,003/2,5999741,co_to_znaczy_szacun_. html [dostęp online: 3.11.2019].

https:// sjp.pwn.pl/poradnia/haslo/Moje-uszanowanie;14948.html [dostęp online: 11.11.2019].

\section{Wykaz źródel}

1) http://weszlo.com/2016/03/30/marcin-duze-pe-matuszewski-czasem-tezmoge-tylko-rozlozyc-rece-i-pierdolnac-sobie-whisky/ [30.03.2016].

2) https://kobieta.wp.pl/stramowski-skomentowal-nagie-zdjecie-zonyjestesmy-pod-wrazeniem-6283205330556545a [11.08.2018].

3) http://www.naszaostroda.pl/index.php?option=com_content\&view=article\&id=1738:ostroda-tak-bdzie-wygldaa-fontanna-za-dwa-miliony\&catid=82: aktualnosci\&Itemid=485 [19.01.2012].

4) http:/ /www.scigacz.pl/3-latek,na,motocyklu,29424.html?utm_source=rss\&amp;utm_medium=link\&amp;utm_campaign=rss-rss [6.09.2016].

5) http://wyborcza.pl/51,75248,22635131.html?i=1 [12.11.2017]. 
6) https:/ / echodnia.eu/swietokrzyskie/grzegorz-piechna-pilkarz-40leciakorony-kielce-wielki-szacun-dla-kibicow-video/ar/8677379 [16.07.2013].

7) https://wagrowiec.naszemiasto.pl/wagrowczanka-zeby-uzyskac-pomoc-wszpitalu-trzeba-byc/ar/c1-4760205 [11.08.2018].

8) http://www.iswinoujscie.pl/artykuly/42918/ [26.05.2016].

9) http://www.luban24.pl/index.php?topic=5810.msg25773\#msg25773 [13.11.2011].

10) http: / / www.luban24.pl/index.php?topic=8738.msg42456\#msg42456 [15.09.2013].

11) http://czestochowa.wyborcza.pl/czestochowa/1,48725,12692831,_Ugotowani_po_czestochowsku_Kulinarnym_mistrzem.html [18.10.2012].

12) http://limanowa.in/wydarzenia/news,26303.html [19.11.2015].

13) https: / / krytykakulinarna.com/kotlownia-ja-to-szanuje-warszawa / [9.03.2015].

14) http://www.radoshe.pl/index.php/2018/09/14/lato-wloski-lato-zrobilam-to-znow/ [14.09.2018].

15) https:/ /warszawa.wyborcza.pl/warszawa/1,54420,9827274,Nowa_knajpa_ obok_Hiltona_Sciema_czy_szacuneczek_html [24.06.2011].

16) http:/ /weszlo.com/2019/04/16/trzydziestka-trzydziestu-najlepsi-sezoniezasadniczym/ [16.04.2019].

17) http: / /www.mmwroclaw.pl/457041/2013/8/20/konkurs-mm-wygrajbilety-na-enemef-z-woodym-allenem?category=news [20.08.2013].

18) https:/ / 40ton.net/komis-ciezarowkami-sprzedaje-wielblada-najbardziej-ek ologiczny-ciagnik-historii-transportu/ [8.05.2014].

19) http:/ / kasiagandor.com/2014/03/modelki-sa-grube/ [10.03.2014].

20) https: / / tldrtldr.wordpress.com/2013/12/22/definicja-normalnosci / [22.12.2013].

21) http: / / marudersi.forumpl.net/t767-eliksiry-to-nie-gotowa-wiedza-musisz-probowac [14.07.2014].

22) http:/ / www.emito.net/spolecznosc/fora_tematyczne/motoryzacja/polski_ samochod_w_szkocji_przez_rok_232916 [5.08.2005].

23) https: / / gdziewyjechac.pl/37138/besdkidzka-zima-w-naszym-nowym-obiektywie.html [26.01.2016].

24) https:/ / www.wykop.pl/wpis / 17208583/czolem-mirunie-mam-problemstrzelila-mi-obrecz-w-z/ [3.04.2016].

25) http:/ /wszechmysli.blogspot.com/2015/07/wakacje.html [5.07.2015].

26) https: / forum.pclab.pl/topic/ 159721-Pascal-Szukam-kogos-chetnego-do-pomocy/ [23.04.2006]. 
Szacun, szacuneczek, uszanowanko! On derivatives expressing respect (?)

\section{Summary}

A trend for manifesting various attitudes and feelings by means of derivatives of the nouns szacunek, uszanowanie, and poszanowanie (respect) is noticeable in modern Polish. However, their meanings and grammatical statuses are unclear. Therefore, this paper aims to characterise units such as szacun, szacuneczek, uszanowanko as well as poszan and poszanowanko in terms of grammar and semantics. They are formally analysed by describing their structure and their semantic interpretation is made based on an overview of the material excerpted using Mocno PL, a corpus search engine, and Google, a web search engine. The analyses lead to the conclusion that the examined derivatives are stylistic synonyms of the noun szacunek in certain contexts only. In a majority of cases, they express approval, while in some contexts they function also as formulas opening or closing a statement or an utterance.

Keywords: word formation, morphological neologism, colloquial Polish

Trans. Monika Czarnecka 